\title{
Production of an enterotoxin by a gastro-enteritis- associated Aeromonas strain
}

\author{
C. J. TROWER, S. ABO, K. N. MAJ EED* and M. VON ITZSTEIN
}

Departments of Medicinal Chemistry and *Pharmaceutics, Monash University, 381 Royal Parade, Parkville, Victoria 3052, Australia

\begin{abstract}
The potential of motile Aeromonas species to cause human gastrointestinal infections has been recognised recently. Considerable worldwide epidemiological, microbiological and clinical investigations have shown that some strains of the different motile aeromonads are of increasing enteropathogenic significance, especially in children, the elderly and in immunocompromised individuals. Some of the diarrhoeal symptoms of Aeromonasassociated gastro-enteritis have been attributed to enterotoxins. In this study, 15 Aeromonas isolates from clinical and non-clinical sources, representing the three motile aeromonads commonly associated with gastro-enteritis (A. caviae, A. hydrophila and A. veronii biovar sobria), were tested for their ability to cause fluid accumulation in infant mice by the suckling mouse technique. Eight isolates were found to produce enterotoxin. Of these, an A. veronii biovar sobria strain (AS15), isolated from lamb kidney, was found to produce the highest enterotoxin score. An enterotoxin of c. $40 \mathrm{kDa}$ produced by A. veronii biovar sobria AS15 was purified by Sephacryl S-100 gel filtration and highperformance liquid chromatography. This enterotoxin caused marked fluid accumulation in infant mice by the suckling mouse technique. The purified enterotoxin cross-reacted with cholera toxin antibodies and was readily inactivated by heating at $56^{\circ} \mathrm{C}$ for $10 \mathrm{~min}$. The production of a 'cholera-like' enterotoxin by Aeromonas isolates from samples of animal origin suggests that these organisms could be of public health significance in food products.
\end{abstract}

\section{Introduction}

The genus Aeromonas represents a group of gramnegative, facultatively anaerobic and oxidase-positive organisms that are currently classified, along with the much better known Vibrio cholerae, in the family Vibrionaceae. However, molecular evidence has shown that they possess an evolutionary history sufficiently different to warrant a family of their own, the A eromonadaceae $[1,2]$. For systematic, clinical and ecological reasons, aeromonads can be grouped conveniently into the psychrophilic aeromonads of the salmonicida group and the mesophilic aeromonads. The aeromonads of the salmonicida group are non-motile and normally found in surface waters and in bottom sediments whenever certain diseases of fish and other freshwater animals are prevalent. The mesophilic

Received 14 A pril 1999; revised version accepted 20 July 1999.

Corresponding author: Professor M. von Itzstein (e-mail: mark.vonitzstein@vcp.monash.edu.au). aeromonads, in contrast, are mostly motile, with the exception of A. media [3], and have been the topic of recent renewed interest, principally because of increased awareness of their role in human illnesses. $M$ otile Aeromonas species are ubiquitous in nature and have been documented for a long time as autochthonous inhabitants of freshwater and estuarine environments. They can be isolated from many environmental locations, but they are mainly water-borne organisms found in virtually all waters, including chlorinated drinking water [4-11]. However, numerous reports on the incidence of aeromonads in cold-blooded animals, human clinical specimens, food and soil clearly demonstrate that the natural habitats of these organisms are not strictly limited to aquatic environments [12].

M otile aeromonads have been reported to cause a wide range of diseases in both man and animals [10, 13-15]. Human aeromonas infections include skin and soft tissue infections, gastro-enteritis and bacteraemia $[16,17]$. Gastro-enteritis is the most common human illness associated with Aeromonas spp., mainly affecting the young, the elderly and immunocompromised 
patients $[17,18]$. However, illness may also occur in healthy individuals of any age $[17,19,20]$.

Aeromonas species produce a wide range of extracellular toxins and enzymes. Other properties such as adherence, invasiveness and possession of certain surface proteins have also been reported for motile Aeromonas species. Generally, the multiplicity of extracellular products of motile Aeromonas species has led to difficulty in characterising these factors and to disagreement about their properties, as well as about their direct involvement in aeromonas enteropathogenicity. This has resulted in a great deal of controversy and confusion. However, such extracellular biologically active factors as enterotoxins, cytotoxins, haemolysins and proteases have been reported to be produced by motile aeromonads [21-25]. These properties are found more frequently, or better expressed, in strains isolated from diarrhoeal individuals than in those isolated from healthy control individuals or from the environment [26].

It has been well documented that Vibrio cholerae produces enterotoxins and causes profuse watery diarrhoea. The enterotoxins include factors that stimulate cyclic adenosine 3,5-monophosphate (cyclic AMP) production by irreversibly activating the enzyme adenyl cyclase $[27,28]$. The abnormally high cellular levels of cyclic AMP produced as a result stimulate active transport of fluid and electrolytes into the lumen of the small bowel, resulting in a watery diarrhoea. It has been reported that in aeromonas gastrointestinal infections, profuse watery 'cholera-like' diarrhoea is the most common feature $[29,30]$. Furthermore, it has been reported that Aeromonas mutants unable to produce or secrete these enterotoxins show reduced pathogenicity [24].

The present study explored the enterotoxigenic prop- erties of Aeromonas isolates from clinical and non-clinical sources and the isolation and partial characterisation of an enterotoxin from an A. veronii biovar sobria strain are described.

\section{$M$ aterials and methods}

\section{Aeromonas strains}

Fifteen Aeromonas strains were included in this study. They represented the three main phenotypes of motile Aeromonas species (A. hydrophila, A. caviae and A. veronii biovar sobria) and were isolated from different clinical and non-clinical sources (Table 1). All strains were confirmed as Aeromonas species by the oxidase test, resistance to vibriostatic agent $0 / 129$, motility and characteristic reaction in $\mathrm{A}$. hydrophila $(\mathrm{AH})$ medium [31]. They were further confirmed as motile Aeromonas species by the 24E Microbact Test System (M edvet Science, A delaide, A ustralia). Microbact test kits were read after $18-24 \mathrm{~h}$ at $37^{\circ} \mathrm{C}$ and re-examined at $48 \mathrm{~h}$ if definitive results were not obtained. All strains were stored on frozen beads in a cryopreservative fluid (Technical Services Consultants, The Rope Walk, Schofield Street, Heywood, Lancashire OL 10 1DS).

\section{Preparation of cell-free culture filtrates}

For the production of crude enterotoxin, the Aeromonas strains were propagated in Tryptone Soy Broth (TSB; Oxoid) supplemented with yeast extract (Oxoid) $0.6 \%$. They were incubated at $37^{\circ} \mathrm{C}$ with agitation at $150 \mathrm{rpm}$ in an environmental incubator shaker ( $\mathrm{N}$ ew Brunswick Scientific, Edison, NJ, USA) for $24 \mathrm{~h}$. The cultures were then centrifuged in sterile centrifuge tubes at $10000 \mathrm{~g}$ for $30 \mathrm{~min}$ at $4^{\circ} \mathrm{C}$. The resulting supernatant fluids were then filtered through sterile $0.45-\mu \mathrm{m}$ membrane filters (Millipore Medical, Bedford, USA).

Table 1. SMT results of the 15 Aeromonas isolates tested

\begin{tabular}{|c|c|c|c|}
\hline Isolate no. & Species & Source & Enterotoxin score* \\
\hline${ }^{\dagger}$ AC23 (-ve) & A. caviae & Lamb meat (Q|d) & $0.073(-)$ \\
\hline $\mathrm{AC} 27$ & A. caviae & Lamb carcass (QId) & $0.068(-)$ \\
\hline CA 182 & A. caviae & Faeces, weight loss (Tandy) & $0.072(-)$ \\
\hline CA 185 & A. caviae & Faeces (Tandy) & $0.078(-)$ \\
\hline $\mathrm{AHO6}$ & A. hydrophila & Lamb meat (QId) & $0.090(+)$ \\
\hline AH33 & A. hydrophila & Lamb kidney (QId) & $0.065(-)$ \\
\hline CA 05 & A. hydrophila & Diarrhoeal stool (Tas) & $0.066(-)$ \\
\hline CA 191.1 & A. hydrophila & Faeces (Tandy) & $0.087(+)$ \\
\hline P04 & A. hydrophila & Non-diarrhoeal stool (Adel) & $0.068(-)$ \\
\hline A S02 & A. veronii biovar sobria & Lamb meat (Q|d) & $0.092(+)$ \\
\hline A S05 & A. veronii biovar sobria & Lamb faeces (QId) & $0.099(+)$ \\
\hline A S15 & A. veronii biovar sobria & Lamb kidney (QId) & $0.119(+)$ \\
\hline AS16 & A. veronii biovar sobria & Lamb kidney (QId) & $0.106(+)$ \\
\hline CA 18 & A. veronii biovar sobria & Diarrhoeal stool (Tas) & $0.116(+)$ \\
\hline †CA $188.2(+\mathrm{ve})$ & A. veronii biovar sobria & Stool, intermittent diarrhoea (Tandy) & $0.106(+)$ \\
\hline
\end{tabular}

QId, Queensland; Tas, Tasmania; A del, A delaide.

${ }^{*}$ A strain was considered positive $(+)$ if the enterotoxin score was $>0.08$.

†K nown positive and negative controls.

The strain that produced the highest enterotoxin score. 
Cell-free filtrates were stored at $4^{\circ} \mathrm{C}$ for no more than $48 \mathrm{~h}$ until their use in the enterotoxin assay.

\section{Enterotoxin assay}

The suckling mouse technique (SMT) was performed as described previously $[32,33]$ to investigate the ability of the isolates to produce enterotoxin. Appropriate approval for these studies was granted by the $M$ onash University Ethics Committee. One hundred $\mu$ l of each cell-free filtrate containing $2 \mu \mathrm{l}$ of food dye (green SCI44090, McCormack, USA) 2.5\% w/v were injected into the stomachs of 2-4-day-old suckling mice. Three mice were used for each culture filtrate and were kept at $28^{\circ} \mathrm{C}$ for $4 \mathrm{~h}$ after injection before they were killed by cervical dislocation. The ratio of combined intestinal weight to combined remaining body weight was determined. A ratio of $>0.08$ was considered positive for enterotoxin activity. A known enterotoxin-positive strain (CA 188, a diarrhoeal isolate kindly provided by S. Kirov, Department of Pathology, University of Tasmania, A ustralia) and an enterotoxinnegative strain (AC23, isolated from a lamb kidney as described previously) [22] were included in the study as controls.

\section{Isolation of the enterotoxin}

The enterotoxin was isolated by a combination of salt precipitation and chromatographic methods [34, 35]. A large volume of TSB supplemented with yeast extract $0.6 \%$ was inoculated with a 6 -h culture of $A$. veronii biovar sobria (AS15) and incubated under the conditions described earlier. The culture was then centrifuged and filtered as described previously. The cell-free supernatant fluid was then stored in sterile bottles at $4^{\circ} \mathrm{C}$ before further purification.

\section{Ammonium sulphate precipitation}

A mmonium sulphate was added to the supernatant fluid at $50 \%$ saturation and mixed for up to $4 \mathrm{~h}$. The mixture was then centrifuged at $10000 \mathrm{~g}$ for $40 \mathrm{~min}$ at $4^{\circ} \mathrm{C}$. The resulting pellet was redissolved in phosphatebuffered saline (PBS), pH 7.4 (Ajax). This was then dialysed against PBS which was changed three times at 2-h intervals to remove any ammonium salts for safe injection into the mice in the SMT.

\section{Gel filtration and SDS-PAGE}

A sample of the cell-free supernatant fluid (crude enterotoxin) was loaded on to a Sephacryl S-100 gel filtration column $(1.0 \times 120-\mathrm{cm}$ Biorad Econo-column) connected to a protein fractionation system (Pharmacia). The column was packed according to the manufacturer's instructions and equilibrated with PBS until the base line stabilised. Mol.wt standards (Pharmacia) ranging from 13.7 to $67 \mathrm{kDa}$ were run before loading the sample. A volume of $1 \mathrm{ml}$ of PBS, containing $1 \mathrm{mg}$ of protein of the dialysed 'crude enterotoxin', was loaded on to the column. Elution with PBS was applied over a 24-h period at $4^{\circ} \mathrm{C}$. Fractions of $5 \mathrm{ml}$ were collected and the absorbance at $280 \mathrm{~nm}$ was measured for all fractions. Fractions with no apparent protein content were pooled and concentrated with the Amicon $50 \mathrm{ml}$ concentrator (Grace). Individual fractions that corresponded with protein peaks were concentrated and examined by SDS-PAGE $12 \%$ [36]. They were then tested in suckling mice to identify fractions containing enterotoxin activity.

High-performance liquid chromatography (HPLC)

HPLC (Waters, USA) was employed as another method to further purify the crude enterotoxin. The column used was the Protein Pak $60(7.8 \mathrm{~mm}[I \mathrm{D}] \times 30 \mathrm{~cm})$ analytical column. For this experiment, a fresh culture was grown as described earlier, and following the dialysis step the crude enterotoxin was concentrated. A sample of $400 \mu \mathrm{l}$ was run through the HPLC column. PBS was the mobile phase and the flow rate was $1 \mathrm{ml} / \mathrm{min}$. The detection wavelength used was $280 \mathrm{~nm}$ and a retention time of $25 \mathrm{~min}$ was observed. Fractions of $1 \mathrm{ml}$ each were collected from the column and analysed by SDS-PAGE in $12 \%$ gels. The activity of the protein fractions was determined by the SMT.

\section{Heat stability and activity after freezing}

Heat stability was tested by heating the crude enterotoxin preparation in a water bath for $10 \mathrm{~min}$ at $56^{\circ} \mathrm{C}$ [37]. The activity of the protein was subsequently measured in the SMT. The activity of the protein after storage at $-20^{\circ} \mathrm{C}$ for 2 and 3 weeks respectively was also determined by the SM T.

\section{Immunoblotting}

A fter separation on SDS-PAGE, proteins were transferred on to PVDF membranes and then blocked with the chemiluminescence blocking substrate (POD; Boehringer Mannheim). Anti-V. cholerae antiserum (0319 'Bengal'; Denka Seikan, Japan) was diluted to 1 in 300 in blocking solution $0.5 \% \mathrm{w} / \mathrm{v}$ (solution 1) and incubated for $1 \mathrm{~h}$. After washing with TBS containing Tween $200.1 \%$ and solution 1, horseradish peroxidase-conjugated sheep anti-rabbit immunoglobulin (Silenus) diluted to 1 in 1000 in solution 1 was added and incubated for $1 \mathrm{~h}$ as before. Reactivity was detected by using the detection solution of chemiluminescence autoradiography according to the manufacturer's instructions (Boehringer $M$ annheim). Incubation with secondary antibodies was used as a control for non-specificity. 


\section{Results}

\section{Enterotoxin assay}

The results of the enterotoxin assay in suckling mice are shown in Table 1. Of the 15 strains tested, eight (including the positive control) showed positive enterotoxin activity; the other seven lacked this activity. A. veronii biovar sobria strain AS15 was the strongest enterotoxin producer, eliciting marked fluid accumulation in the infant mice. This isolate was chosen for the isolation of the enterotoxin.

Isolation of the enterotoxin (gel filtration and HPLC)

A fter separation by Sephacryl S-100 gel filtration and HPLC, fractions were pooled and concentrated. As shown in Fig. 1, after staining with silver stain, a single band with an apparent mol.wt of c. $40 \mathrm{kDa}$ was obtained on SDS-PAGE. A nother band of c. $31 \mathrm{kDa}$ was also collected (lane 5). Fractions containing these proteins were tested in the SMT as well as other fractions containing no apparent proteins (applied as controls). The only fractions that showed enterotoxin activity were those with the $40-\mathrm{kDa}$ band (Table 1), demonstrating that the enterotoxin isolated by gel filtration and HPLC corresponds to a protein with a mol. wt of c. $40 \mathrm{kDa}$.

\section{Stability to heat and freezing}

The crude enterotoxin was labile to heating in a water bath at $56^{\circ} \mathrm{C}$ for $10 \mathrm{~min}$. Storage at $-20^{\circ} \mathrm{C}$ for 2 weeks did not abolish the activity, although the score obtained after testing in the SMT was reduced from the initial value of 0.119 to 0.086 . After storage for 3 weeks at $-20^{\circ} \mathrm{C}$, the toxin had completely lost activity.

\section{Cross-reactivity with cholera toxin}

The purified toxin reacted with antibodies to $V$. cholerae (0139 'Bengal') in Western blots to give a single band corresponding to the $40-\mathrm{kDa}$ protein (Fig. 1, lane 6).

\section{Discussion}

The work reported here resulted in the isolation of a heat-labile enterotoxin with an apparent mol. wt of $c$. $40 \mathrm{kDa}$ from a gastro-enteritis-associated Aeromonas strain. Enterotoxin production is an important factor in the pathogenesis of Aeromonas-associated gastrointestinal disease. The enterotoxin isolated and purified in this study caused marked fluid accumulation in the SMT, consistent with the production of watery diarrhoea in the aetiology of gastro-enteritis.

The SM T was chosen as the appropriate method for the

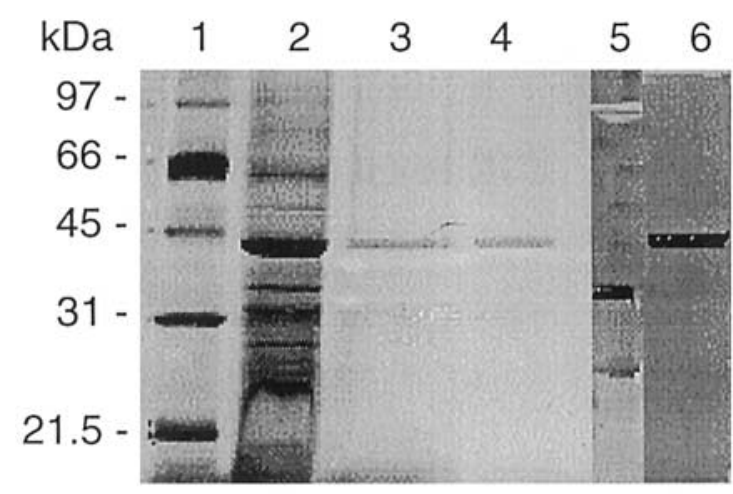

Fig. 1.SDS-PAGE of the purified enterotoxin and other proteins. Lane 1, mol. wt markers; 2, crude enterotoxin; 3, toxin from Sephacryl S-100 gel filtration; 4, purified toxin from HPLC; 5 , fractions containing the $31-\mathrm{kDa}$ protein; 6 , autoradiogram of the $40-\mathrm{kD}$ a protein reacting with anti-cholera antibodies.

detection of enterotoxin, as it is a well accepted technique for detecting enterotoxins produced by other enteropathogenic bacteria, including Escherichia coli [37]. It is also used frequently for the detection of aeromonas enterotoxin $[22-25,37]$. The SMT allows for enterotoxin detection on a larger scale than is possible with the rabbit ileal loop test [30, 37, 38]. A eromonads also produce cytotoxins and cytotoxic enterotoxins; therefore, the SMT has the advantage over cell-culture systems which detect only cytotoxicity [30].

The SMT applied to the 15 Aeromonas isolates used in this study demonstrated that both clinical and environmental isolates are capable of producing enterotoxins. The enterotoxin itself was isolated from an A. veronii biovar sobria strain from lamb kidney, illustrating that meat and other foods may be a source of infection [38-41], even if kept refrigerated, as aeromonads have the ability to survive and produce exotoxins in this cooler environment [42-44]. In this study, the enterotoxin lost its activity when heated at $56^{\circ} \mathrm{C}$ for $10 \mathrm{~min}$, demonstrating the importance of cooking foods adequately to inactivate toxins. This study also confirmed that A. caviae strains (e.g., isolates CA 185 and CA 182) could cause enteric infection without the production of enterotoxin (Table 1), indicating that enterotoxin is not the only factor capable of causing gastro-intestinal disease [45-47].

To our knowledge, this is the first report of the isolation of an enterotoxigenic $40-\mathrm{kDa}$ protein from an A. veronii biovar sobria strain, although a $63-\mathrm{kDa}$ cytotoxic enterotoxin from an $A$. sobria isolate has been described [35]. This study demonstrated that the purified enterotoxin can be stored for 2 weeks at $-20^{\circ} \mathrm{C}$ without losing its activity. M oreover, the crude toxin retained activity if stored below $4^{\circ} \mathrm{C}$ for $<1$ week or frozen at $-20^{\circ} \mathrm{C}$ for $<2$ weeks. The simple and rapid purification processes used in this study also minimised the possible inactivation of the target 
protein; gel filtration took $24 \mathrm{~h}$ and HPLC took only $25 \mathrm{~min}$, a much shorter time than the classical purification techniques. Immuno-adsorption with anticholera toxin antibodies has been employed to purify aeromonad proteins [48]. In this case, three proteins of differing sizes were isolated (27, 29.5 and $43.5 \mathrm{kDa}$ ). The drawback of this process is that only those proteins adsorbed to anti-cholera toxin antibodies were studied, thus excluding any possible non-cholera toxin-reactive enterotoxins.

In the present study, the isolation of enterotoxin was achieved with gel filtration columns, which are widely used and readily obtainable. This method produced a pure protein that retained its activity for several days. It will be interesting to apply this method to the isolation of other active proteins from other aeromonad isolates.

In summary, a highly purified protein of c. $40 \mathrm{kDa}$ in size was isolated from an aeromonad strain known to cause gastro-enteritis. This protein isolation procedure used gel filtration and was able to produce a pure protein that was active in the SMT. This result was reproduced with the more sensitive process of HPLC. The toxin itself was heat labile and could not be stored for $>3$ weeks at $-20^{\circ} \mathrm{C}$. It was also cross-reactive with V. cholerae (0139 'Bengal') antiserum and this may indicate that the enterotoxin causes its diarrhoeal symptoms by a mechanism similar to that of cholera toxin [49]. Further studies are needed to obtain more information about the specificity and other activities related to this enterotoxin. Furthermore, the determination of its amino-acid sequence and three-dimensional structure may provide information on the aeromonad enterotoxins in general, and their specific role in enteric illness.

\section{R eferences}

1. Colwell RR, MacDonell MT, De Ley J. Proposal to recognize the family of Aeromonadaceae fam. nov. Int J Syst Bacteriol 1986; 36: 473- 477.

2. Janda JM, Duffey PS. Mesophilic aeromonads in human disease: current taxonomy, laboratory identification, and infectious disease spectrum. Rev Infect Dis 1988; 10: 980-997.

3. Allen DA, Austin B, Colwell RR. Aeromonas media, a new species isolated from river water. Int I Syst Bacteriol 1983; 33: 599-604.

4. Burke V, Robinson J, Gracey M, Peterson D, Partridge K. Isolation of Aeromonas hydrophila from a metropolitan water supply: seasonal correlation with clinical isolates. Appl Environ Microbiol 1984; 48: 361-366.

5. Burke V, Robinson J, Gracey M, Peterson D, Meyer N, Haley V. Isolation of Aeromonas spp. from an unchlorinated domestic water supply. Appl Environ Microbiol 1984; 48: 367-370.

6. Burton GA, Lanza GR. Aeromonas hydrophila densities in thermally-altered reservoir water and sediments. Water Air Soil Pollut 1987; 34: 199-206.

7. Ghanem EH, Mussa ME, Eraki HM. Aeromonas-associated gastroenteritis in Egypt. Zentrabl Mikrobiol 1993; 148: 441- 447.

8. Krovacek K, Faris A, Baloda SB, Lindberg $T$, Peterz $M$, $M$ ånsson I. Isolation and virulence profiles of Aeromonas spp. from different municipal drinking water supplies in Sweden. Food Microbiol 1992; 9: 215-222.

9. Knøchel $S$, Jeppesen C. Distribution and characteristics of
Aeromonas in food and drinking water in Denmark. Int J Food Microbiol 1990; 10: 317-322.

10. Kühn I, A lbert MJ, A nsaruzzaman $M$ et al. Characterization of Aeromonas spp. isolated from humans with diarrhea, from healthy controls, and from surface water in Bangladesh. J Clin Microbiol 1997; 35: 369-373.

11. Kühn I, Allestam G, Huys $G$ et al. Diversity, persistence, and virulence of Aeromonas strains isolated from drinking water distribution systems in Sweden. Appl Environ Microbiol 1997; 63: 2708-2715.

12. Majeed $\mathrm{KN}$. Motile Aeromonas species in lamb samples with special reference to their exotoxigenic properties. PhD thesis, Queensland University, Queensland, A ustralia, 1992.

13. Cunningham AA, Langton TES, Bennett PM et al. Pathological and microbiological findings from incidents of unusual mortality of the common frog (Rana temporaria). Phil Trans R Soc Lond B Biol Sci 1996; 351: 1539-1557.

14. Kodjo A, Haond F, Richard Y. Molecular and phenotypic features of aeromonads isolated from snails (Helix aspsersa) affected with a new summer disease. Zentrabl Veterinarmed 1997; 44: 245-252.

15. Marcus LC. Infectious diseases of reptiles. J Am Vet Med Assoc 1971; 159: 1626-1631.

16. Jones $\mathrm{BL}$, Wilcox $\mathrm{MH}$. Aeromonas infections and their treatment. J Antimicrob Chemother 1995; 35: 453-461.

17. King GE, Werner SB, Kizer KW. Epidemiology of Aeromonas infections in California. Clin Infect Dis 1992; 15: 449-452.

18. Deodhar LP, Saraswathi K, Varudkar A. Aeromonas spp. and their association with human diarrheal disease. J Clin Microbiol 1991; 29: 853-856.

19. Caudell MJ, Kuhn WF. Aeromonas hydrophila soft-tissue infection: a report of two cases. Acad Emerg Med 1997; 4: 157- 158.

20. Gold WL, Salit IE. Aeromonas hydrophila infections of skin and soft tissue: report of 11 cases and review. Clin Infect Dis 1993; 16: 69-74.

21. Janda JM. Recent advances in the study of the taxonomy, pathogenicity, and infectious syndromes associated with the genus Aeromonas. Clin Microbiol Rev 1991; 4: 397-410.

22. Majeed K, Egan A, MacRae IC. Enterotoxigenic aeromonads on retail lamb meat and offal. J Appl Bacteriol 1989; 67: $165-170$.

23. Majeed KN, Macrae IC. Cytotoxic and haemagglutinating activities of motile Aeromonas species. J Med Microbiol 1994 40: 188- 193.

24. Merino $S$, Rubires $X, K$ nøchel $S$, Tomàs $J M$. Emerging pathogens: Aeromonas spp. Int J Food Microbiol 1995; 28: 157- 168.

25. Vadivelu J, Puthucheary SD, Phipps M, Chee YW. Possible virulence factors involved in bacteraemia caused by Aeromonas hydrophila. J Med Microbiol 1995; 42: 171-174.

26. Kirov SM, Sanderson K. Aeromonas: recognising the enemy. Today's Life Sci 1995; Nov: 30-35.

27. Cassel D, Pfeuffer T. Mechanism of cholera toxin action: covalent modification of the guanyl nucleotide-binding protein of the adenylate cyclase system. Proc Natl Acad Sci USA 1978; 75: 2669-2673.

28. Gill DM, Meren R. ADP-ribosylation of membrane proteins catalyzed by cholera toxin: basis of the activation of adenylate cyclase. Proc Natl Acad Sci USA 1978; 75: 3050-3054.

29. Watson IM, Robinson J O, Burke V, Gracey M. Invasiveness of Aeromonas spp. in relation to biotype, virulence factors, and clinical features. J Clin Microbiol 1985; 22: 48-51.

30. Stelma GN. Aeromonas hydrophila. In: Doyle MP (ed) Foodborne bacterial pathogens. York: Marcel Dekker. 1987: $1-19$.

31. Kaper J, Seidler RJ, Lockman H, Colwell RR. Medium for the presumptive identification of Aeromonas hydrophila and Enterobacteriaceae. Appl Environ Microbiol 1979; 38: 1023- 1026.

32. Megraud $F$. Incidence and virulence of Aeromonas species in feces of children with diarrhea. Eur J Clin Microbiol 1986; 5: 311- 316.

33. Wong CYF, Mayrofer $G$, Heuzenroeder MW, Atkinson $H M$, Quinn DM, Flower RLP. Measurement of virulence of aeromonads using a suckling mouse model of infection. FEMS Immunol Med Microbiol 1996; 15: 233-241.

34. M CCardell BA, Madden JM, Kothary MH, Sathyamoorthy V. Purification and characterization of a $\mathrm{CHO}$ cell-elongating 
toxin produced by Aeromonas hydrophila. Microb Pathog 1995; 19: 1-9.

35. Potomski J, Burke V, Watson I, Gracey M. Purification of cytotoxic enterotoxin of Aeromonas sobria by use of monoclonal antibodies. I Med Microbiol 1987; 23: 171- 177.

36. Laemmli UK. Cleavage of structural proteins during the assembly of the head of bacteriophage T4. Nature 1970; 227: $680-685$.

37. Johnson WM, Lior H. Cytotoxicity and suckling mouse reactivity of Aeromonas hydrophila isolated from human sources. Can J Microbiol 1981; 27: 1019-1027.

38. Krovacek K, Faris A, Baloda SB, Peterz M, Lindberg T, $M$ ånsson I. Prevalence and characterization of Aeromonas spp. isolated from foods in Uppsala, Sweden. Food Microbiol 1992; 9: $29-36$.

39. Hudson JA, M ott SJ, Delacy KM, Edridge AL. Incidence and coincidence of Listeria spp., motile aeromonads and Yersinia enterocolitica on ready-to-eat fleshfoods. Int J Food Microbiol 1992; 16: 99- 108.

40. Khurana R, Kumar A. Prevalence of motile aeromonads in foods of animal origin. J Food Sci Tech 1997; 34: 228-229.

41. Singh U. Isolation and identification of Aeromonas spp. from ground meat in eastern Canada. J Food Protect 1997; 60: $125-130$.
42. Beuchat $L R$. Behaviour of Aeromonas species at refrigeration temperatures. Int J Food Microbiol 1991; 13: 217- 224.

43. Kirov SM, A rdestani EK, Hayward LJ. The growth and expression of virulence factors at refrigeration temperature by Aeromonas strains isolated from foods. Int J Food Microbiol 1993; 20: 159-168.

44. Krovacek K, Faris $A, M$ ansson I. Growth of and toxin production by Aeromonas hydrophila and Aeromonas sobria at low temperatures. Int J Food Microbiol 1991; 13: 165-176.

45. A shdown LR, Koehler JM. The spectrum of Aeromonasassociated diarrhea in tropical Queensland, A ustralia. Southeast Asian J Trop Med Public Health 1993; 24: 347-353.

46. Figura N, Marri L, Verdiani S, Ceccherini C, Barberi A. Prevalence, species differentiation, and toxigenicity of Aeromonas strains in cases of childhood gastroenteritis and in controls. J Clin Microbiol 1986; 23: 595-599.

47. Wilcox MH, Cook AM, Eley A, Spencer RC. Aeromonas spp as a potential cause of diarrhoea in children. J Clin Pathol 1992; 45: 959- 963 .

48. Potomski J, Burke V, Robinson J, Fumarola D, M iragliotta G. Aeromonas cytotonic enterotoxin cross-reactive with cholera toxin. J Med Microbiol 1987; 23: 179-186.

49. Jesudason MV, Jacob-John $T$. The appearance and spread of Vibrio cholerae 0139 in India. Indian J Med Res 1994; 99: 97- 100. 